\title{
GENDER IN NATIONAL HISTORY NARRATIVES IN SOCIAL STUDIES TEXTBOOKS FOR GHANA
}

\author{
DOI: http://dx.doi.org/10.17159/2223-0386/2019/n21a4 \\ Clement Sefa-Nyarko \\ Alexander Afram \\ Melbourne, Australia \\ Participatory Development Associates \\ University of La Trobe \\ Accra, Ghana \\ sefanyarko@yahoo.com \\ aafram12@gmail.com
}

\section{Abstract}

The Ghanaian society is highly patriarchal and one of the immediate outcomes is that assignment of roles and responsibilities are typically based on gender lines. This paper is about gender representation in social studies textbooks in Ghana for Junior High School (JHS) students. In this article we argue that this inherent division of responsibilities based on gender navigates into history textbook narratives and influences the roles that are assigned to male and female characters. We further argue that male characters are assigned more superior roles than female characters in Ghanaian history textbooks, albeit subtly. The article uses the Ghanaian social studies textbook for JHS which documents historical accounts of Ghanaian men and women in precolonial, colonial and postcolonial periods. Both content and thematic analyses were used to present evidence for the findings. The contents of the selected textbooks sections were organised into two types of narratives to establish how gender is represented and whether one gender is systematically undermined in the texts. This helped to summarise the content into themes. Firstly, we assessed the representation of male and female characters in the texts to ascertain the extent to which females and males are represented in the narratives. Secondly, we assessed the language used in the textbooks to show if the language and specific key words used favoured particular gender groups. In this article we conclude that linking men to more prestigious occupations and heroic undertakings of the past and silencing of women in such positions, is subtle but predominant in the treatment of history in Ghanaian JHS social studies textbooks. Consequently, we recommend the development of a gender-sensitive policy to mainstream gender neutrality in curriculum development and textbooks contents.

Kevwords: Gender; History; Social studies; Ghana, Textbook.

\section{Introduction}

Gender is a social construction of roles and relationships for members of different sexes (male, female or other) ${ }^{1}$ in such a way that they are

1 Admittedly, sex as a biological outcome is not simply a categorical phenomenon of male and female, but a 
categorized into dichotomies of boys and girls, men and women, with specific roles and models of interacting with each other. Gendered roles and behaviours are conspicuous in Ghana (Anyidoho, Tagoe, Adjei, Appiah, Yeboah-Banin, Crentsil, Oduro-Frimpong, Owusu \& Torvikey, 2016; Acheampong, 2000; Clark, 2000; Duncan \& Brants, 2004; Overa, 2007), Africa (Grosz-Ngate, 1997) and the world over (McDowell, 1997). This has found its way into the construction of history and representations in school curricula and textbooks. Gender representation in education is exhibited at various levels of curricula and extra curricula activities, and from one educational system to another (Blumberg, 2007). This paper analyses gender biases in the narratives of history in Junior High School (JHS) social studies textbooks in Ghana, from the 1980s to the present. Ghana is one of the countries where work and other human activities are clearly delineated along gender lines, from precolonial, colonial and present times. Again, in Ghanaian culture, feminine names are often used to refer to tenderness, caring, reproduction and love among others, while masculine names are often used to refer to physical activity, leadership, brevity and the like (Cole, 2007). This phenomenon of using gender to represent different character roles has found its way into textbooks. The paper thus attempts to examine how this view of society finds its way into one of the main textbooks (social studies) for lower secondary school students which first introduces young learners to the way of life of Ghanaian society.

According to the UN (2011), Gender Parity Index (GPI) at primary school has stagnated at 0.96 since 2007, and that for Junior High School it is even lower, at 0.92 . This "poses a challenge to women participation in decisionmaking at higher levels and their access to wage employment and higherlevel occupations" in Ghana (UN 2011:para 4). Among other things, norms and societal attitudes tend to discourage women from engaging in wage employment and some occupations such as commercial driving, welding, and auto-mechanics account for this (UN 2011). Other factors include culturally instigated domestic workload for girls, and unfriendly classrooms and shortage or lack of toilet facilities in public schools.

Many scholars believe that formal education has often reinforced gender biases through school curricula, syllabuses, textbooks, the school setting and teachers' classroom practices (Alayan \& Al-Khalidi, 2010; Thompson,

continuum of many categories that lie between male and female, including hermaphrodites. For clarity of expression, however, the dualism of male and female shall be used throughout the discourse. 
2003; Miller, 1993; Riddell, 1992). Teachers can be unaware of this because they are simply teaching how they were taught (Chapman n.d.:para 18). Consequently, "subtle inequalities found in history curricula and textbooks are either overlooked" (Chapman, n.d.:para 18) or unnoticed by teachers. In effect, even though boys and girls study in the same classrooms, use the same textbooks and may be taught by the same teacher, they may end up receiving different messages (Sadker \& Sadker, 1994), which affect the psychological wellbeing, expectations and growth of learners (Lesikin, 2001). This has implications for gendered relationships, socialization and development of self-esteem. Curriculum, textbooks and what teachers teach therefore require close scrutiny, especially the construction and representation of gender in a people's history.

The next section presents a background to the gender question in Ghana and elsewhere, including a theoretical framework. Following that is a literature review, methodology, presentation and discussion of findings and conclusions.

\section{Background to the gender question in Ghana}

In Ghana and many African countries, females are largely credited with home management, domestic tasks such as cooking, washing, cleaning, sweeping, fetching water, childcare among others and cleaning activities in school that arguably involve less physical strength. Males, on the other hand, assume leadership roles at homes and are expected to take roles that demand physical strength including weeding, pounding and lifting of loads. Yet, it is difficult to point out homogenous standards of gender roles and relationships among the over 100 ethnic groups in Ghana. Many gender roles and relationships are not complementary. Some scholars have argued that uncomplementary gender roles and relationships are the result of colonial interventions that eliminated complementary gender arrangements and provided equal opportunities for both males and females at homes, on the farms, in the economy and in entrepreneurship (Aidoo, 1985; Arhin, 1983; Sudurkasa, 1986). Others have argued that colonial rule in Africa only reinforced existing gender norms that were repressive of females (Bakare-Yusuf, 2003).

Currently, gender roles and relationships are changing for both males and females in an increasingly liberal society (Wrigley-Asante, 2011), due to acculturation in an ever- deepening global world (Fening, 2015) although this view is not shared by all scholars on gender. After extensive study of 
the Asante culture for instance, Clark (2000) admitted that there is constant negotiation and "renegotiation" of gendered roles and relationships but was not convinced that these are overhauling the gendered systems in place. This "constant renegotiation" does not indicate "their weakness or imminent disappearance" but indicates that "they remain valuable sociocultural assets that give powerful leverage" to those who wield power in society (Clark, 2000:727). Anyidoho et al., (2016) found that female role models and attainment of higher education for both male and females can bring about change.

Women are expected to dominate in the marketplace and other informal employment settings (Clark, 2000; Overa, 2007; Acheampong, 2000). For instance, whilst the proportion of women in the economic sector in Ghana increased from 39 percent in 1960 to 51 percent in 1984 (Baden et al., 1994:6), the proportion of those involved in skilled production remained at 8.8 percent by 1988 (GSS, 1988). According to the 2010 Population and Housing Census, 69 percent of males and 65 percent of females are engaged in different kinds of economic activities; however, of those in the public and private formal sector, the proportion of males is twice that of females. Women's workload in domestic chores is approximately 25 percent greater than that of men (World Bank, 2002). Whilst women spend about two and half hours a day on unpaid chores at home, men spend about 40 minutes a day (GSS, 2009). The gravity of this statistic is compounded by the phenomenon of the glass ceiling (Tsikata, 2007), which is the prevalence of systemic impediments that prevent many competent women from rising to the highest ranks in the public sector.

Overa (2007) particularly referred to retail market activities as female occupation in urban centres until the 1980s, when it became attractive to males after the Structural Adjustment Programme led to massive job losses for males. Overa referred to certain stereotypes about male and female behaviours in public. In the business of retailing, "unfeminine" behaviours like using "physical strength", "talking loudly", displaying "self-acquired wealth" or "exercise of power" were "morally" justified for women due to the nature of their job (Overa, 2007:540). Two conclusions could be drawn. Firstly, males are not expected to engage in retailing and petty trading, except under very harsh economic conditions (Overa 2007), for which they are expected to adopt certain face-saving strategies. Secondly, only males are expected to display physical strength and opulence. 
In farming communities, gendered division of labour is also still present. Women do the "planting, weeding, watering, harvesting, the transportation of farm produce, agro-processing and the marketing of small amounts of farm produce" (Duncan \& Brants, 2004:3). Men, on the other hand, clear wild bushes for initial cultivation, till the soil, and are more concerned with cash crop cultivation than food crop cultivation (Duncan \& Brants, 2004; Benneh, Kasanga \& Amoyaw, 1995). According to Benneh et al., (1995), food crop production is not capital and labour intensive, and could be cultivated on less fertile lands, compared to cash crops. Men, therefore, prefer to leave these to the care of women, who usually do not own the land. Married women are also expected to assist their husbands on their farms, even where they also have their own farms to attend to (Duncan \& Brants, 2004).

Childcare is also a women's job (Clark, 2000), often associated with the reproductive role of females. The female is expected to be the daughter, wife, mother and grandmother; even though she is also expected to stand up to financial challenges of childcare and to provide all the needs of her children (Clark, 2000; Manuh, 1997; Overa, 2007), often referred to as the productive role in the household. Both male and female are expected to participate in the productive activities to ensure economic sustainability of the household (Duncan \& Brants, 2004). If a male is employed and has a regular source of income, he is expected to be the breadwinner, support the female and take care of the children. If, on the other hand, the male is unable to be the breadwinner, or decided voluntarily not to do so, he does not have to bear any responsibility. "Women do not have that choice" (Overa, 2007:556). They remain constant in the social calculus of childcare, from birth through breastfeeding to all other issues of upbringing. Among the Ashanti of Ghana, for example, despite the centrality of the woman in childcare, "a woman who overemphasizes income-generating work is seen as neglecting her husband, not her children" (Clark, 2000:717). This underscores the woman's domestic role, making her principally a mother and wife, together with being a daughter and grandmother.

Women are expected to be subordinates, whilst men are expected to lead (Wrigley-Asante, 2011). The traditional role of men is to be heads of households and decision makers, and for women to be under men's leadership. A man is expected to lead due to "his economic advantage and his control over productive resources" in many traditional societies (Wrigley-Asante, 2011:61). The female (the wife) is expected to be 
"subordinate and submissive owing principally to her lower socioeconomic status" (Wrigley-Asante, 2011:61). Green (1997:23) asserts that even in pre-colonial Africa, where some historians claim that women also held leadership positions in religious, political, economic and social institutions, "their roles and activities did not have the same prestige as those of men". Women's political authority was subordinated to that of men (Green, 1977); and only very few women held prestigious religious leadership positions (Guy, 1990; Musisi, 1996). This situation was accentuated by colonial patriarchal cultures and has persisted to date and continues to affect the power relations between male and female members of society (Wrigley-Asante, 2011; Duncan \& Brants, 2004). Nevertheless, Wrigley-Asante (2011:81) observed that "the increasing economic position of women in the home is changing the traditional status of women", which has challenged the dominant leadership role of men.

\section{Gender equality dynamics in Ghanaian schools}

Since the 1980s, education has been acknowledged as a strategic tool for achieving gender parity in Ghana. Prior to this era, and up to the early 1990s, school dropout rate was 46 percent for girls and 36 percent for boys. It was generally held, especially in rural areas, that "the private costs of educating girls are ... higher than for boys" (Baden, Green, Otoo-Oyortey \& Peasgood 1994:iv), making many parents prefer to invest more in the education of boys. This has, among others, entrenched roles and norms that feed on gender stereotypes, limited women's access to job opportunities and reduced their confidence to insist on their social and civic rights (Gender Policy of the YMCA, 2011). The educational reform of 1987 was the first milestone in tackling the gender question in Ghana. It eliminated gender streaming in subjects in elementary schools and made gender equity a national agenda. Ten years later, the Ministry of Education introduced the Free Compulsory Universal Basic Education (FCUBE), which further heightened the urgency for gender mainstreaming. It eliminated costs associated with basic education and prioritized girl-child education. Numerous policies like school feeding programmes, Capitation Grant and free school uniforms for basic schools were expected to shore up enrolment in primary school and increase gender parity in basic schools (See GES 2001). This higher premium placed on girlchild education was directly influenced by the 1995 Beijing Conference on women, which heightened the urgency for both boys and girls to have equal access to education. 
Despite these, the Ghana Education Service (GES) acknowledged that the school environment and learning materials put girls at a disadvantage in its 2004 presentation at the United Nations (UN) conference on education in Geneva. Educational policies and reviews have attempted at addressing this challenge. Gender inequity gaps have been targeted through two curriculum development options: (1) syllabus development and (2) textbooks development (GES 2004:8).

The Curriculum Research and Development Division (CRDD) of the Ghana Education Service, which is the unit responsible for curriculum development in basic schools, has received a series of capacity building initiatives on gender mainstreaming and gender capacity analysis (Camfed, 2012; MacKinnon, 2002). These are intended to eliminate gender biases in content and teaching-learning activities and to ensure that learning outcomes accrue equally to all learners irrespective of gender. Whilst Mackinnon (2002), as reported by Camfed (2012) found no evidence of the impact of the trainings on girls' educational outcomes, it found evidence of enhanced ability and skills of teachers and CRDD staff to analyse, review and develop gender sensitive curricula (See Camfed, 2012). These notwithstanding, there is still evidence of gender biases, albeit subtle, that needs to be re-examined to bridge the systemic gap in the education environment.

\section{Representation of gender in textbooks}

Textbook presentations of gender, and specifically the role of women in economic and political history, reflect their authors' perception of women in society. Curricula are generally represented in various forms for learners' consumption, including through textbooks as core reference material for teaching and learning. Textbooks "interpret curriculum policies in a way that reflects the views of authors, publishers and reviewers" (Pinto, 2007:99). Textbooks for learners convey "knowledge and skills [that] students ought to achieve" (Ato, 2009:28). It is estimated that learners spend about 80 percent to 95 percent of their classroom time using textbooks while teachers make most of their instructional decisions based on textbooks (Blumberg, 2007; Sadker \& Zittleman, 2007; Baldwin \& Baldwin, 1992).

In textbooks, the issue of gender and equality are at play in two major ways - verbal text and image representations. Research on gender representation in textbooks in sub-Saharan Africa (Fardon \& Schoeman 2010; Mkuchu 2004; Schoeman, 2009) and North Africa, Asia and the Middle East (Alayan 
\& Al-Khalidi, 2010; Bahman \& Rahimi, 2010; Kallab, 1981; Alrabaa, 1985; Shtaiwi, 1999; Jassey, 1998), have all confirmed the gendered roles and representations in textbooks that undermine female aspirations for careers in engineering, medicine and other outdoor occupations. Many other studies have also confirmed these gendered perspectives in textbooks (See Miller, 1993; Blumberg, 2007; Weitzman et al., 1972; Sadker \& Sadker, 1980; Sadker \& Zittleman, 2007; Botkin 2007). A comparative study by Jassey (1988:88) made this profound statement:

Virtually all the studies concluded that textbooks have not adequately reflected the range of women's roles and occupations in the real world. In general, it seems gender biased images remain strongly present in school textbooks throughout the world.

In a cross-country analysis of gender biases in textbooks, Blumberg (2007:5) found that almost all content analyses were telling essentially the same story, with minor variations. Except for Fould (2013) who did not find any significant biases in Kenyan textbooks, almost all the studies on gendered representations in textbooks found some significant differences. Blumberg (2014:1) sums these up as: less representation of females than males; attribution of stereotyped gender roles where females are associated with motherhood, tenderness, sacrifice, household, domestic chores and unskilled labour (See also Alayan \& Al-Khalidi, 2010; Staiwi, 1999), and males are given prestigious occupations and characterised by courage, autonomy, leadership and creativity. Even in countries where some improvement in these biases are found over time, these changes are "more often slow (even glacial) than rapid" (Blumberg, 2014:1).

Bahman and Rahimi (2010) have found that despite cultural variations across different Anglophone regions, the English language that is used for textbooks is biased against females in five main ways. ${ }^{2}$ This resonates with what other scholars have agreed upon, that language and text can be manipulated to serve ideological, political (Sefa-Nyarko, 2016) and socio-cultural purposes (Rahimi \& Sahragard, 2006; Mills, 1995; Lee, 1992). The five ways identified by Bahman and Rahimi (2010) are the preference for "male-biased terms" like bachelor and master over feminine terms like spinster and mistress; use of "male-generics" to refer to both male and female like man and mankind; ${ }^{3}$ biases in the allocation of titles

2 English is the official language used in Ghanaian textbooks, and so understanding the gender biases inherent in its conversational form is important.

3 This overshadows females and could have an overpowering effect on their self-esteem (Sadka and Sadka 1995). 
- Mr. for both married and unmarried men and Mrs and Miss for married and unmarried women respectively ${ }^{4}$ - the male primacy in the order of presentation of male and female like "he or she" and "Adam and Eve" (See also Goddard \& Patterson, 2000:57); and the preference for males as protagonists in stories and naming (See also Weatherall, 2006; Poynton, 1989). In this gendered naming, women protagonists, few as they may be, like Cinderella and Snow White, are presented as objects for the attention of a hero who is usually a male; or as villainous old women.

\section{Representation of gender in History textbooks}

In a global review of literature, Chiponda and Wassermann (2011) found three main themes in the representation of females in history textbooks, which also resonate with findings from other scholars (Fardon \& Schoeman, 2010; Osler, 1994; Muravyeva, 2006; Chick, 2006).

Firstly, in terms of roles and activities, women in history textbooks are "portrayed in stereotypically traditional feminine roles in a domestic environment" (Chiponda \& Wassermann, 2011:15). Both males and females are presented to reinforce existing norms, customs and traditions, where males are rulers, soldiers, and engineers; and females are wives, mothers, dancers and generally subordinated to men (See also Fardon \& Schoeman, 2010; Osler, 1994). In Russian textbooks, women political leaders were presented as villains associated with revenge and failure in war (Muravyeva, 2006). In South Africa, males are presented as active, assertive and curious, whilst females are dependable, conforming and obedient (Fardon \& Schoeman, 2010). Male-oriented activities in South African societies were mentioned 64 times in those history textbooks whilst no mention of female-oriented occupations was mentioned (Fardon \& Schoeman, 2010).

Secondly, women are under-represented in history textbooks, and the difference has been found to be statistically significant by numerous studies (Chiponda \& Wassermann, 2011; Cornish, Carinci \& Noel, 2012; Chick, 2006; O'Kelly, 1983; Sadker \& Sadker, 1994; Reese, 1994). O’ Kelly (1983) found, for instance, that women and men were featured 30 percent and 70 percent respectively in art works in history textbooks. Blumberg (2007), citing Alrabaa (1985) reported 463 occupations for males and females in their analysis of Syrian textbooks. However, 84 percent (391)

4 Although "Ms" is becoming a popular hybrid for women of all categories, Bauer et al. (2006:164) believe that it is often interpreted to be a "title for divorced, separated or widowed women". 
of the occupations were filled by males and 16 percent (72) by females. In a review of a history textbook in the United States, Sadker and Sadker (1994) reported that the book dedicated only 3 percent of the content to women; and only 8 women had a paragraph dedicated to them. Anyidoho et al., (2016) admitted that history production in Ghana has neglected to acknowledge the significant role of women in nation building.

Thirdly, although sexist language that directly undermined, demeaned or excluded both females and males is generally avoided, texts, content and images are presented from a male perspective (Chiponda \& Wassermann, 2011). Male characters are used often, and there is a general preference and primacy for the male, whilst female characters are associated with beauty and complementarity (Fardon \& Schoeman, 2010).

\section{Theoretical framework}

We proceed on the assumption that gender representation and narratives in textbook contents are directly shaped or informed by existing policy guidance on curriculum and content development. Thus, in societies where gendersensitivity specific policies on curriculum and content development are absent, such as Ghana, authors of textbooks are at liberty to represent narrations in textbooks by gender characters based on their conception of gendered roles in their immediate social environment. The outcome of this gender-blind policy environment could either produce gender neutral contents or gender-biased contents, based on existing sociocultural beliefs and practices on gender roles. In the case of Ghana where the society is patriarchal, this is likely to favour male characters more than female characters.

This assumption is influenced by the social relations framework, proposed by Kabeer $(1994)^{5}$ which has been used widely to analyse the gender relations in the distribution of resources, responsibilities and power, and how these are shaped through institutions and policies. It assumes that poverty or inequality is borne out of unequal social relations. Gender relations is one such example, where roles and responsibilities are shaped along resource allocation. ${ }^{6}$ Females, especially those in poor and disadvantaged societies, are often excluded and must rely on relations of dependency and patronage for access to resources and survival. These relations are however not finite and can be changed through human agency

$5 \quad$ N Kabeer, Reversed realities: Gender hierarchies in development (Verso 1994).

6 International Labour Organisation (1998). Online gender learning and information module; a conceptual framework for gender analysis and planning. 
at the macro level. Institutions produce, reproduce and reinforce social relations, including differences in assigning roles and inequality. Gender inequality, and by extension biases in representation, are thus reproduced not just at the household or communal level, but through institutions and policies at the state, community and local levels. Gender analyses must peruse how institutions and gender specific policies on curriculum, or the lack of them affect gender representation or narratives in school textbooks.

\section{Methodology}

Three main editions of the social studies textbooks have been published since Ghana's most comprehensive educational reforms in 1987. Social studies textbooks are the main source of history teaching and learning materials for all learners in Junior High School in Ghana. These were published in 1988, 2005 and 2008. The 1988 textbooks were authored and published by the Ministry of Education and Culture (MOE) while the 2005 and 2008 versions were written by Quansah and Otu, 2005; and Amoah, Baabereyir, Cobbinah, Dake, and Ngaaso (2008), with approval from the Ministry of Education. Prior to the educational reforms of 2001, the Ministry of Education published, printed, and distributed all pre-university textbooks. After the 2001 Educational Reforms, the publication and printing were privatised to allow private stakeholders to participate in the process. This explains why the 1988 textbook was authored and published by the $\mathrm{MoE}$ and the later versions by private publishers. The MoE and the Ghana Education Service reserved the right to approve and authorise distribution of approved textbooks for use in schools. New social studies textbooks have been published since 2008 but these have not been included in our analysis since they do not deviate significantly from the 2005 and 2008 editions. This study analyses historical narratives of gender biases from the editions of the JHS social studies textbooks described above.

Sections from all three textbook versions dealing with environmental, cultural, socioeconomic and political history of Ghana were analysed in this paper. We focused on these sections because of our interest in the presentation of history in the textbooks. See table 1 for complete details of the books used and the specific chapters or sections analysed. 
Tabel 1: The list of Social Studies textbooks reviewed

\begin{tabular}{|c|c|c|c|}
\hline Book title/s & $\begin{array}{l}\text { Year Published \& } \\
\text { Publisher }\end{array}$ & Authors & $\begin{array}{l}\text { Sections } \\
\text { Analysed }\end{array}$ \\
\hline $\begin{array}{l}\text { Social Studies for } \\
\text { Junior Secondary } \\
\text { Schools, Book } 1\end{array}$ & $\begin{array}{l}1988 \\
\text { Curriculum Research } \\
\text { and Development } \\
\text { Division, Accra }\end{array}$ & $\begin{array}{c}\text { Ghana Education } \\
\text { Service }\end{array}$ & Pages 4-112 \\
\hline $\begin{array}{l}\text { Social Studies } \\
\text { for Junior High } \\
\text { Schools 1, } \\
\text { Revised edition }\end{array}$ & $\begin{array}{l}2008 \\
\text { Adwinsa } \\
\text { Publications, Accra. }\end{array}$ & $\begin{array}{c}\text { E Amoah, A } \\
\text { Baabereyir, J } \\
\text { Cobbinah, G Dake, } \\
\text { and C Ngaaso }\end{array}$ & Pages $47-88$ \\
\hline $\begin{array}{l}\text { BECE Social } \\
\text { Studies for JSS, } \\
\text { pupil's Book } 1\end{array}$ & $\begin{array}{l}2005 \\
\text { Sedco Publishing } \\
\text { Limited, Accra }\end{array}$ & $\begin{array}{c}\text { KB Quansah, \& CE } \\
\text { Otu }\end{array}$ & Pages 2-59 \\
\hline $\begin{array}{l}\text { BECE Social } \\
\text { Studies for JSS, } \\
\text { pupil's Book } 3\end{array}$ & $\begin{array}{l}2005 \\
\text { Sedco Publishing } \\
\text { Limited, Accra }\end{array}$ & $\begin{array}{c}\text { KB Quansah, \& CE } \\
\text { Otu }\end{array}$ & Pages $35-49$ \\
\hline
\end{tabular}

The Quansah and Otu (2005) edition analysed for this paper comes in three sets (books one, two and three). Book one was produced to meet the needs of the first year Junior High School (JHS 1) syllabus and treats issues like migration of ethnic groups in Ghana, arrival of Europeans in the Gold Coast, cultural expressions, natural resources and production. Book two deals with JHS 2 syllabus and introduces learners to the geography of Ghana, environmental protection, state and private enterprises, the constitution of Ghana and governance processes and international cooperations. In book three, which is for JHS 3, learners are exposed to the issues of nationalism and the struggle for independence, political stability, and general problems of development in Ghana and rural-urban migration. For the purpose of this paper, only book one and book three were usedbecause book two contains no historical accounts to be included in the analysis.

The 1988 edition published and circulated by the Ghana Education Service also had books one, two and three, however, only book one was used in the review and analysis, since it is the only edition that treated historical narratives of Ghana. This book is divided into three parts: part one treats the general geography of Ghana and the local environment, part 
two considers the socio-cultural structure and organisation of Ghanaian society and part three is devoted to the treatment of history of migration and political struggle for independence in Ghana.

The books were selected purposively to meet the objective of the paper, that is, to analyse the representation of gender in junior high school textbooks in Ghana. Since social studies is the only subject that treats history, culture, socioeconomic and everyday life matters at the junior high school level of education in Ghana, the various editions provided content to adequately support the purpose of this paper.

Both content and thematic analyses were used to present evidence for the paper. The content of the selected textbooks sections was organised into two types of narratives to establish how gender is represented and whether one gender is systematically undermined in the texts. This helped to summarise the contents into main themes that have been presented in the subsequent sections. Firstly, we assessed the representation of male and female characters in the content of the texts to ascertain whether one gender is projected in the narratives. Secondly, we assessed the language used in drafting those sections of the textbooks to show if the language and specific key words used favoured one gender more than the other. The outcomes from these two levels of content analysis were organised into themes as follows 1) use of male and female attributes, 2) political history narrative of pre-colonial, colonial and postcolonial times in Ghana, 3) social and economic development history narrative and 4) cultural history narrative. Thereafter, thematic analysis of gender representation and narratives was used based on the themes outlined above.

\section{Presentation and discussion of the findings}

The following sections discuss findings from the review of the historical narratives in the social studies textbooks.

\section{Political history of pre-colonial, colonial and postcolonial times in Ghana}

The presentation of historical narratives of pre-independence political persuasions in JHS1 to JHS3 textbooks is very silent on the active role of women in that entire political period and in leadership processes.

Also, from page two to page 17 of Quansah and Otu (2005a) that talks about ancient Ghana history, covering politics, chieftaincy, trade and 
culture, no female character was mentioned even though 26 male names (mainly chiefs) were mentioned, giving the impression that only men engaged in the socio-political activities at the time. For example:

In the year 1203, Sumanguru and his army from Susu, a state within the Ghana Empire, also conquered Ghana (Quansah \& Out, 2005a: 2).

Even though women (queen mothers) played critical roles in the traditional political (chieftaincy) administration by influencing key decisions, acted as kingmakers, trade facilitation, etc. such roles are often overlooked, or at best understated in textbook historical presentations of pre-colonial political and governance processes (Botkin, 2007; Bradford, 1996). This does not only relate to textbooks, but in general construction of history. Bradford (1996), for instance noted, "Women are not merely neglected; their existence is often conceptually denied" (Bradford 1997:352). Similarly, Anyidoho et al., (2016) admitted that history production in Ghana has failed to acknowledge the significant role of women in nation building. This is perhaps an offshoot of the patriarchal structure of the Ghanaian traditional society which primarily subordinates women's roles to those of men. It could also be a pure institutional problem where lack of gender sensitive policies guiding the production of textbook contents has further entrenched the male-dominant narratives. This thinking is supported by Kabeer's (1994) social relations framework discussed earlier in this paper. Few attempts are made in some sections to balance generic use of gender, albeit still projecting male characters as the most dominant. Consider the extract below:

The chief is thought of as being above everybody. He is therefore highly respected. He makes laws for the people and judges cases. But he does not do all the things alone. He is helped by a council of elders. Some of the members of council are the queen mother, the family heads and the linguist (GES, 1988: 109).

Aside from the superior role of male characters in the historical presentations, we see attempts to balance the representation of male and female characters in some versions of the textbooks, which is good. For instance, the use of dialogue, featuring a male and a female in a conversation is used widely to represent gender in some versions of textbooks, mainly the versions published prior to the year 2000. For example, in the JHS 1 social studies book published in 1988, 14 out of 18 chapters used dialogue of equal male and female representation (GES, 1988:1-84). Here are some extracts modelled as conversation in class: 
$\mathrm{Kofi}^{7}$ : Please, Sir, you gave an example of a representative fraction of 1:1000. Would you explain what it means?

Ama: ${ }^{8}$ Sir, I've noticed that in writing the representative fraction both the numerator and the denominator must be in the same unit. (GES 1988: 6).

What Ama said made Kofi remember what he had heard some time ago. He had heard his elder brother and one of his friends talking about how to make a map (GES, 1988: 7).

This is a conscious attempt to represent both male and female voices in some of the textbooks. However, the style of representation has changed in the books published from 2000. They no longer use dialogue and the texts are largely gender neutral, except where history, sociocultural practices and independence political discourses are discussed. These topics have overwhelming male dominance in their presentations. The attempt to summarise some of the narratives in the latter versions have left it with narratives that reinforce existing gender socialisation.

Moreover, there are inbuilt biases that present males as the dominant actors or role models in historical presentation of political activities before, during and after independence. For instance, in JHS 3 textbooks, the writings on colonialism and independence struggles mentioned no female in both economic and political activities, whether in an active or supporting role. Even though names of foreign nationalists such as Mahatma Ghandi, Jomo Kenyatta and Namdi Azikiwe ${ }^{9}$ found their way into the JHS 3 social studies textbook when treating nationalist activities that led to independence in Ghana; no female (local or foreign) or feminine influence was mentioned, except Yaa Asantewaa, who is mentioned in passing despite her significance in national history. Yaa Asantewaa was cited as the leader of the Asante Kingdom and its army as follows:

The Asante army was led by Yaa Asantewaa who the queen-mother of Ejisu was. Though the Asante fought hard, they were completely defeated (GES, 1988: 6).

Yaa Asantewaa is a prominent figure in the colonial history of the Gold Coast and the interaction of the colonial administration with the Asanti Kingdom. She was the Queen Mother of Ejisu, who lived from 1840 to 1921 (Adu-Boahene \& Akyeampong, 2003). Extra-curricular narratives by Adu-Boahene and Akyeampong explain that during the Asante-British

\footnotetext{
Kofi is a male and a Friday born

Ama is a female name meaning a Saturday born

Namdi was the first president of Nigeria after gaining independence in 1963. His rule ended in 1966.
} 
war of 1900/1901, she demonstrated bravery against the British colonial troops that were at war with the Asante Kingdom. They provide edifying accounts of her successful leadership of the Ashanti Kingdom after the arrest of her brother and chief of Edweso, Afrane Kumaa in 1896. She became the queen and king of the state, and subsequently acted with bravery and excellence. In giving account of her role in the Ashanti army during the era of the British conquests in the Gold Coast during the 1900s she is described as follows:

Yaa Asantewaa ... instigated and precipitated the uprising. Lt. Col. Montanaro, one of the leading British officers, called Yaa Asantewa ... one of the prime movers in the rebellion. The Basel Missionary Obrecht, based in Abetifi, in his letter of 30 July 1900 called her the soul and head of the whole rebellion. Armitage and Montanaro also described her as the old queen-mother of Ejisu, whose name has figured so largely in the rebellion ... (Adu-Boahene \& Akyeampong, 2003: 120).

It must be mentioned that, not even the extra-curricular sources have much documentary evidence of involvement of other women in political activities in Ghana. This tells a lot about the gender dynamics at the preindependence, independence and post-independence era in Ghana.

\section{Social and economic development history}

Socioeconomic history in the JHS textbooks also has more roles and records of men than of women. In the area of education, Ghanaian nationals like John Mensah Sarbah, Casely Hayford and Attoh Ahuma, are repeatedly cited as key contributors (Quansah \& Otu, 2005a:32). There is no female cited as having contributed to educational development in the Gold Coast. One may be tempted to argue that no female played an active role during the colonial and precolonial eras; but that is not an accurate assumption. In fact, the narratives as presented are indicative of the social structure that existed in that era. Again, this goes to confirm the underrepresentation of females in history textbooks as alluded to by many authors (Chiponda \& Wassermann, 2011; Anyidoho et al., 2016; Botkin, 2007; Bradford, 1996). For example, during the signing of economic treaties, some local chiefs were mentioned but no queen mother was referenced. The extract below speaks to this fact:

The chiefs who signed the declaration were Nana Kwadwo Tibu VI, Chief of Denkyira; Nana Kwasi Otu, Chief of Abora; Nana Tibu Kuma, Chief of Assin; Nana Gyebra, another Chief of Assin; Nana Kwasi Anka, Chief of Dominansi; Nana Awisu, another Chief of Dominasi; Nana Amoono, Chief 
of Anomabo and Nana Joseph Aggrey, Chief of Cape Coast (Quansah \& Out, 2005a: 34).

These were the chiefs who reportedly signed the Bond of 1844-a treaty ${ }^{10}$ between the British and local chiefs. A possible explanation for no female representation may be for the simple reason that females/queen mothers were not called to represent hence no records for them were documented. This position has been challenged by Anyidoho et al. (2016) and is discussed in detail ahead in this section.

Some statements from the textbooks give empirical support to the dominant role of males (chiefs, native doctors etc.) in historical writings on socioeconomic persuasions:

In the reign of Nana Akumfi Ameyaw I, from 1328 to 1363, Bono expanded its kingdom through conquests, and increased its richness through the gold trade. Akumfi Ameyaw introduced the use of gold dust as currency. He also introduced gold weights as measures of value and established the position of "sanaahene" or minister of finance (Quansah \& Otu, 2005a: 8).

Sanaa Hene [finance male chief] was responsible for commercial matters as well as setting the price of commodities (Quansah \& Otu, 2005a: 8).

Here, there is emphasis on the king as taking all important economic and political decisions and influencing change, although female political leaders (queen mothers) have traditionally and historically played an active role in the structure and organization of trade and other forms of commercial activities (Mensah et al., 2014). Although the dominant role of women in socioeconomic activities (trade) throughout history cannot be overlooked, there is no indication in the history narratives in the textbooks to emphasise this. This supports the claim of Bradford (1996) that women's existence in history is often conceptually denied by historians and authors. Anidoho et al., (2016) have alluded to the displeasure of scholars to this silencing of women as follows:

And although women have been made largely invisible in the narratives of nation-building in Ghana - a fact to which female scholars drew attention during the 50 th anniversary of Ghana's independence in 2007 - women have made great contribution to the development of the Ghanaian state and economy (Anyidoho et al., 2016: 6).

No account of a woman is given in the textbooks as having contributed to the development of education or any other social service in the country.

10 A peace agreement signed between the British government and some sudden chiefs in Ghana. The agreement allowed the British government and its military to usurp powers of African courts. It intended to allow the British government or military to offer protection to the southern states from Asante invasion. 
References to actors in socioeconomic processes did not give any recognition to females. Male names such as Tetteh Quarshie, FC Grant, Thomas Hughes, JE Ellis, JP Brown and JE Biney are mentioned in the narratives without reference to any female character engaged in business or contributing to economic activities. Masculine words like "businessmen" and "middlemen" are used to refer to people who were involved in trade and other socioeconomic ventures during the colonial era, as if to suggest that women played no role in commercial activities at the time (Quansah \& Out, 2005a:8, 36-58; GES, 1988:91-104; Quansah \& Out, 2005:36).

The incidence of male-dominated historical narratives in instructional textbooks is not only in Ghana or in Africa, but a near global phenomenon (Fardon \& Schoeman, 2010; Mkuchu, 2004; Schoeman, 2009; Alayan \& Al-Khalidi, 2010; Bahman \& Rahimi, 2010; Kallab, 1981; Alrabaa, 1985; Shtaiwi, 1999; Jassey, 1998; Miller, 1993; Blumberg, 2007; Weitzman et al., 1972; Sadker \& Sadker, 1980; Sadker \& Zittleman, 2007; Botkin, 2007). This is evidenced by the overrepresentation of males in the accounts of colonial and postcolonial economic engagements, negotiations and treaties.

Some scholars insist that in spite of systematic relegation of women to domestic spaces (Tsikata \& Darkwah, 2013; Allman, 1996; Anhyidoho et al., 2016), they made substantial contribution to the social and economic constructs of Ghana (Anyidoho, et al., 2016); which ought not to be overlooked in history.

Despite these constraints, women carved out spaces for themselves in the informal economy mainly as food crop farmers and traders. By the late 1970s and 1980s, female traders had gained great income and power from their work and had leveraged that power (consolidated through associations) to become a powerful economic and social force (Anyidoho et al., 2016:5). Some of the military interventions of the 1970s and 1980s may have thrown the economic gains of both men and women into disarray; and Manuah (1993) believes that these restored the influence of men in socio-economic spaces.

\section{Cultural history}

The historical presentations on culture try to balance the power and representation of masculine and feminine elements. For example, in most cases, whenever a generic masculine term like "grandfather" or "chief" is 
used to illustrate a point, a feminine term like "grandmother" or "queen mother" is also used:

The chief is thought of as being above everybody. He is therefore highly respected. He makes laws for the people and judges cases. But he does not do all the things alone. He is helped by a council of elders. Some of the members of council are the queen mother, the family heads and the linguist (GES, 1988: 109).

Cultural history is an important aspect of the JHS social studies curriculum in Ghana. The narratives of how ancestors of different traditional societies organized their lives politically, socially and economically through indigenous institutions such as chieftaincy, clans and ethnic groups tell a gender story. Some historians argue that pre-colonial Ghanaian societies had complementary gender relations, independence of both male and female, and equal rights to properties, economic enterprise and social protection (Anyidoho et al., 2016; Aidoo, 1985; Arhin, 1983). Others like Bakare-Yusuf (2003) argue instead, that colonial rule merely reinforced existing gender inequalities in African societies generally.

Although culture is displayed to provide equal space for both males and females, the position of the chief, household head and family heads are mostly reserved for males. This is prevalent in the treatment of such issues as festivals, family, environment and religion. However, in presenting culture in the textbooks, there is specific reference to "queen mothers" as models for women, spelling out the active role of women in traditional politics of ancient Ghana. This section also makes direct reference to queen mothers as the ones historically responsible for the search and selection of kings and chiefs:

When a stool in the family becomes vacant, a new chief is elected. The selection is done by a group of people known as the kingmakers. These include the queen mother, the head of the family and some elders of the villages and towns (GES, 1998:108).

This is an attempt to say that females have a voice in the traditional kingmaking process; although females themselves are not eligible to be selected as chiefs or kings in the Ghanaian traditional context. Therefore, on one breath, the representation of character roles in the textbooks maybe a true reflection of what actually existed based on how the Ghanaian society was structured in terms of roles for males and females. 


\section{Conclusion}

The construction of gender identities, linking men to more prestigious occupations and heroic undertakings of the past and silencing of women in such positions, is subtle but predominant in the treatment of history in Ghanaian JHS social studies textbooks. This is consistent with the genderspecific pathways of gender-sensitive policies proposed by Kabeer (1994). Gender biases play a subtle but influential role in the organisation of society regarding the assignment of domestic and professional roles. Some of these delineations are intrinsic in the socio-cultural values and orientations of societies, hence very difficult to eliminate from socioeconomic and political construction of society, even when efforts are made. This underpins identity creation of all societies. Whilst attempts have been made by the Ministry of Education through the Ghana Education Service to mainstream gender in curriculum development, there remains more to be done. Curiously, no female author was found among the authors of the social studies textbooks reviewed. Both male and female role models in history ought to be explicitly presented for learners to effect change in attitudes and practices about gender from the early years.

While existing policies on curriculum appear to be gender-neutral, the sociocultural underpinnings of Ghanaian society inherently assign dominant roles to males rather than females. It is therefore necessary to have specific guidance for authors to present gender roles in school textbooks equally. For example, males are represented as armies and combative forces - a symbol of leadership, brevity and control. Women are hardly mentioned in ancient Ghana in wars, armies and other forms of activities that involved risk taking and physical confrontations in the textbooks. Names such as Sumanguru, Opoku Ware I, Akumfi Ameyaw I, Frempong Manso, Obiri Yeboah, Kwame Nkrumah, Osei Tutu and Komfo Anokye; ${ }^{11}$ and terms like "kingdom", "middlemen", and "institution of kingship" dominate the narratives of pre-colonial, colonial, and postcolonial political, social and economic organization. The words "kingdom" and "kingship" are masculine words that seem to suggest that the entire geopolitical enclave is under the male king. This projects male rulers in history as superior to their female counterparts. Botkin (2007) calls this male dominance in narratives as sexism. According to him, sexism is a "system of advantages that serves to privilege men, subordinate women, denigrate women-identified values

11 These are males who are widely associated with the Ashanti Kingdom and other Akan ethnic groupings that contributed to pre-colonial and colonial socio-political arrangements. 
and practices, enforce male dominance and control, and reinforce forms of masculinity that are dehumanizing and damaging to women" (Botkin, 2007:174).

Again, the originally male dominant characters with prestigious roles in textbooks could be for the fact that existing policies guiding their development were gender-blind and often favoured males rather than females due to socially constructed roles for males and females. This is likely to maintain the status quo - males will continue to dominate character representations in textbooks. However, policies could also be gendersensitive, and gender-sensitive policies may produce three outcomes. Firstly, such policies could be gender-neutral which tends to leave the distribution of resources, roles and responsibilities intact for generations. Secondly, policies could be gender specific. Gender-specific policies tend to meet or protect targeted needs of one gender within resource distribution and assignment of responsibilities in content development. This may also either maintain or even widen existing biases. Finally, policies could be gender redistributive. Here, interventions are focused on transforming existing distributions regarding resources, roles and responsibilities towards a more egalitarian end. We recommend that government policies on education and curriculum reforms should pursue the latter to guarantee equal representation of both genders in textbook narratives in the future.

\section{References}

Acheampong, E 2000. Wope tam won peba (You like cloth but you don't want children): Urbanization, individualism, and gender relations in colonial Ghana, c. 1900-1939. In: D Anderson and R Rathbone (eds.), Africa's Urban Past. Oxford: James Currey, 222-234.

Adu-Boahen, A and Kwaku Akyeampong, E 2003. Yaa Asantewaa and the Asante-British War of 19001. Oxford: James Currey publishers.

Aidoo, AA 1985. Women in the history and culture of Ghana. Research Review, 1(1):14-51.

Alayan, S and Naseema, A-K 2010. Gender and agency in history, civics and national education textbooks of Jordan and Palestine. Journal of Educational Media, Memory and Society, 2(1):78-96.

Allman, J 1996. Rounding up spinsters: Gender chaos and unmarried women in colonial Asante. The Journal of African History, 37(2):195-214. 
Alrabaa, S 1985. Sex division of labour in Syrian school textbooks. International Review of Education, 31(3):335-348.

Amoah, E, Baabereyir, A, Cobbinah, J, Dake, G and Ngaaso, C 2008a. Social studies for junior high schools 1, Revised edition. Accra: Adwinsa Publications.

Anyidoho, NA, Tagoe, CA, Adjei, M, Appiah, E, Yeboah-Banin, AA, Crentsil, A, OduroFrimpong, J, Owusu A, and Torvikey, D 2016. Shakesphere lives in Ghana: Roles, representations, perceptions of women in contemporary Ghanaian society. ISSER final report for SLIG Project.

Arhin, K 1983. The political and military roles of Akan women. In: C Oppong (Ed.), Female and male in West Africa. London: George Allen and Unwin.

Ato, EM 2009, A critical study of textbook publishing for primary education in Ghana. A Doctoral dissertation submitted to the School of Graduate Studies, Kwame Nkrumah University of Science and Technology, Kumasi.

Baden, S, Green, C, NaanaOtoo-Oyortey and Peasgood, T 1994, Background paper on gender issues in Ghana, Report No. 19 prepared for the Department for Overseas Development (DFID). Brighton: Institute for Development Studies.

Bahman, M and Rahimi, A 2010, Gender representation in EFL materials: An analysis of English textbooks of Iran high schools, Procedia Social and Behavioural Sciences, 9:273-277.

Bakare-Yusuf, B 2003. Yorubas don't do gender: A critical review of Oyewumi's. The invention of women: Making an African sense of Western gender discourse (pdf). Available from CODESRIA website: http://www.codesria.org. Accessed in September 2018.

Baldwin, P and Baldwin, D 1992. The portrayal of women in classroom textbooks, Canadian Social Studies, 26(3):110-114.

Bauer, L, Holmes, J and Warren, P 2006. Language matters. New York: Palgrave Macmillan.

Benneh, G, Kasanga, RK and Amoyaw, D 1995. Women's access to agricultural land in the household: A case study of three selected districts in Ghana. Accra: FADEP.

Blumberg, RL 2014. Eliminating gender bias in textbooks: Pushing for policy reforms that promote gender equity in education. A background paper prepared for Education for All Global Monitoring Report 2015, titled: "Education for All 2000-2015: Achievements and challenges", ED/EFA/MRT/2015/PI/24, presented to UNESCO in Paris in June 2015. 
Blumberg, RL 2007. Gender bias in textbooks: A hidden obstacle on the road to gender equality in education. A background paper prepared for Education for All Global monitoring report 2008, Number 2008/ED/EFA/MRT/PI/18. Available at http://www.unesdoc.unesco.org/images/0015/001555/155509e. pdf. Accessed in September 2018.

Botkin, SJ 2007. Sexism Curriculum Design. In: MB Adams, Teaching for diversity and social justice: 173-194. New York, London: Routledge.

Bradford, H 1996. Women, gender and colonialism: Rethinking the history of the British Cape colony and its frontier zones, c. 1806-1870. The Journal of African History, 37(03):351-370.

Camfed G 2012. What works in girls. Education in Ghana: A critical review of the Ghanaian and international literature, for the Ministry of Education and the Girl's Education Unit of the Ghana Education Service, 2012.

Chapman, A (n.d.). Gender bias in education, Critical Multicultural Pavilion Research Room online. Available at http://www.edchange.org/multicultural/papers/ genderbias.html. Accessed on 7 August 2015.

Clark, G 1999. Mothering, work, and gender in urban Asante ideology and practice. American Anthropologist, 101(4):717-729.

Cole, Catherine M 2007. Give her a slap to warm her up: Post-gender theory and Ghana"s popular culture. In: CM Cole, TakyiwaaManuah and SF Miescher (eds.), Africa After Gender? Bloomington and Indianapolis: Indiana University Press:270-284.

Cornish, DM, Carinci, S, Noel, J 2012. Gender representation in AP ART History Textbooks. In: H Hickman, BJ Porfilio (eds), The New Politics of the Textbook. Constructing Knowledge (Curriculum Studies in Action), 1. Sense Publishers, Rotterdam

Duncan, BA and Brants, C 2004. Access to and control over land from a gender perspective: A study conducted in the Volta Region of Ghana. Available at http://www.fao.org/3/a-ae501e.pdf. Accessed on 5 August 5, 2015.

Eisner, EW and Vallance, E 1974. Five conceptions of curriculum, their roots and implications for curriculum planning. In: EW Eisner and E Vallance (eds.), Conflicting conceptions of the curriculum. Berkeley, C. A.:McCutchan:1-18.

Fening, PA 2015. The changing face of the Ghanaian culture: A case of earring in men, Asian Journal of Humanities and Social Sciences, 3(1):110-119. 
Ghana Education Service (1988). Social Studies for Junior Secondary Schools, Book 1. Curriculum Research and Development Division, Ghana Education Service, Accra, Ghana.

Ghana Education Service (2001), A national vision for girls. Education in Ghana and a framework for action: Charting the way forward. Girls Education Unit, Basic Education Division.

Ghana Education Service (1988). Social Studies for Junior Secondary Schools, Book 1. Curriculum Research and Development Division, Ghana Education Service, Accra, Ghana.

Ghana Statistical Service (GSS) 2009. Ghana Time Use Survey 2009: How Ghanaian women and men spend their Time. Accra: Ghana Statistical Service.

Goddard, A and LM Patterson 2000. Language and gender. London: Routledge.

Grosz-Ngate, M 1997. Introduction. In: M Grosz-Ngate and OH Kokole (eds.), Gendered encounters: Challenging cultural boundaries and social hierarchies in Africa. New York: Routledge:1-22.

Guy, J 1990. Gender oppression in Southern Africa's precapitalist societies. In: C Walker (ed.), Women and gender in Southern Africa to 1945. London: James Currey:33-47.

Jassey, I 1998. Gender in elementary school texts. Japan Quarterly, 45:87-93.

Kallab, I 1981. She cooks, he reads: The image of women in textbooks in Lebanon. Beirut: Institute for Women Studies in the Arab World.

Lee, D 1992. Competing discourses: Perspective and ideology in language. London: Longman.

Lesikin, I 2001. Determining social prominence: A methodology for uncovering gender bias in ESL textbooks. In: Innovation in English Language Teaching. London: Routledge:275-282.

McDowell, L 1997. Capital culture: Gender at work in the City. Oxford: Blackwell Publishers Ltd.

Mensah, CA, Kwabena Barima Antwi and Suleman Dauda 2014. Female traditional leaders (Queen Mothers) and community planning and development in Ghana. Environmental Management and Sustainable Development, 3(1): pp. 205-220.

Mkuchu, SGV 2004. Gender roles in textbooks as a function of hidden curriculum in Tanzania primary schools. Unpublished Doctoral Dissertation, University of South Africa, Pretoria. 
Miller, J 1993. Constructions of curriculum and gender. In: S KnoppBiklen and D Pollard (eds) Gender and Education, $1^{\text {st }}$ edition. Chicago: National Society for the Study of Education:43-63.

Musisi, Nakanyike B 1996. A personal journey into custom, identity, power, and politics: Researching and writing the life and times of Buganda's Queen Mother Irene Drusilla Namaganda (1896-1957). History in Africa, 23:369-385.

Overa, R 2007. Why men do women"s work: Structural adjustment, umemployment and changing gender relations in the informal economy of Accra, Ghana. Journal of Modern African Studies, 45(4):539-563.

Pinto, LE 2007. Textbook publishing, textbooks, and democracy: A case study. Journal of Thought, 42(12).

Poynton, C 1989. Language and gender: Making the difference. Oxford: Oxford University Press.

Quansah, KB \& Otu, CE 2005a. BECE Social Studies for JSS pupil's, Book 1. Sedco Publishing Limited, Accra, Ghana.

Rahimi, A and Rahman, S 2006. A Critical Discourse Analysis of euphemization and derogation in e-mails on the late Pope. The Linguistics Journal, 2(2):29-87.

Riddell, Sheila I. (1992), Gender and the Politics of the Curriculum (London: Routledge).

Sadker, D and Zittleman, K 2007. Gender bias from Colonial America to today's classrooms. In: JA Bank and CA McGee Banks (eds.), Multicultural education: Issues and perspectives. Hoboken, NJ: John Wiley and Sons Inc.:135-169.

Sadker, Myra and David Sadker (1994), Failing at Fairness: How America”s schools cheat girls (New York: Touchstone Press).

Sadker, M and Sadker, D 1980. Sexism and teacher education text. Harvard Educational Review, 50:36-46.

Schoeman, S and Fardon, J 2010. A feminist post-structuralist analysis of an exemplar South African School History Text. South African Journal of Education, 30:307-323.

Schoeman, S 2009. The representation of women in a sample of South African School History Textbooks. South African Journal of Education, 29:541-556. 
Sefa-Nyarko, C 2016. The Impact of the varying narratives of Ghana's post independent violence in textbooks since 1987. In: D Bentrovato, KV Korostelina and M Schulze (eds.), History can bite: History education in divided and postwar societies. Gottingen: Vandenhoeck \& RuprechtUnipress GmbH:61-84.

Shtaiwi, M 1999. Al-Adwar Al-Jandarya Fi Al-Kutub Al-MadrasiyaLilmarhala AlAsasiya Fi-Al-Ordon (Gender Roles in Textbooks for the Basic Stage in Jordan). Amman: UNESCO.

Thompson, Audrey (2003), "Special series on girls and women in education: Caring in context: Four feminist theories on gender and education", Journal of Curriculum Enquiry, vol. 33, No. 1, 9-65.

Tsikata, D 2007. Gender, institutional cultures and the career trajectories of faculty of the University of Ghana. Feminist Africa 8: Rethinking Universities I, 8:26-41.

Tsikata, D \& Darkwah, A 2013. Employment. In: Ghana Social Development. Outlook 2012. Accra: Institute of Statistical, Social and Economic Research.

Weatherall, A 2006. Gender, language and discourse. New York: Taylor and Francis.

Weitzman, LJ, Eifler, D, Hokada, E and Ross, C 1972. Sex-role socialization in picture books for pre-school children. American Journal of Sociology, 77:11251150 .

World Bank 2002. Ghana: Strategic Country Gender Assessment, Briefing note for the Ghana Poverty Reduction Strategy. Available at http://siteresources. worldbank.org/EXTAFRREGTOPGENDER/Resources/GhanaCGA-R.pdf. Accessed on 11 March 2015.

Wrigley-Asante, C 2011. Women becoming bosses: Changing gender roles and decisionmaking in Dangme West District of Ghana. Ghana Journal of Geography, 3:60-87. 